species mentioned, in the best collection of its sort $I$ have seen. $M$. Dandelot has the gift of portraying the authentic facial expression, which makes his animals live. Even the mongooses (surely the acid test) look like mongooses, and the Felidae are superb. Though correctly described in the text, both the steenbok and Sharpe's grysbok are depicted with false hooves, an unfortunate slip.

This excellent book can be recommended to everyone with an interest in African mammals, professional as well as amateur.

W. F. R. ANSELL

\title{
Australia's National Parks, by Vincent Serventy. Angus and Robertson, 85s.
}

In $A$ Continent in Danger, published in 1966, Vincent Serventy warned that many of Australia's unique plants and animals might be threatened with extinction, and in this latest work he repeats his warning. But he also gives a cheering account of the progress made in the conservation of at least a representative series of habitats, with their natural plant and animal communities, in parks and reserves 'where all things of nature are protected'. Royal National Park, near Sydney, the first national park in Australia, and the second in the world, was established in I879. 'Today there are many national parks and reserves throughout the country-and more are being declared each year'. Of these he has selected I8I to give an overall picture of Australia's native flora and fauna. The descriptions, done with admirable clarity and interest, bring out each reserve's special aspect or task, and the text is interwoven with magnificent illustrations: 32 full-page colour photographs, 64 pages of black and white.

Some Australian parks and reserves are very large. The South-west National Park in Tasmania, for example, embraces approximately I,600,000 acres. The conservationist might prefer to have a much smaller area with more assurance about the plans for its long-term maintenance; management, a matter to which Serventy makes little reference, may be essential to achieve the 'special task' of a reserve. Even in Australia, because 'each year millions of acres of bushland are destroyed . . . marshes are drained ... rivers are dammed', the largest reserves may prove ecologically unstable and subject to dynamic change if left to themselves.

This account of Australian flora and fauna, and their natural habitats, is a valuable contribution to the conservation literature; it is no less enjoyable reading - and viewing - for any reader with an interest in a lovely country. Whether one has had the good fortune to have seen some of these unique plants and animals amid their native scenery, or whether the book itself introduces them for the first time, the interest and pleasure it will give can be assured.

JOHN BERRY

Since Silent Spring, by Frank Graham Jnr. Hamish Hamilton, 40s. Silent Spring was a skilful advocacy of the case that the indiscriminate use of pesticides has had undesirable and damaging effects on organisms other than target species. Mr Graham begins with an interesting biographical sketch of the late Rachel Carson, and gives the background to her book which so severely rocked the agro-chemical boat. His own book follows in the same vein, and again deals largely with the situation in the United States, but includes relevant details drawn from other countries. The more recent scientific evidence supporting Miss Carson's case is marshalled, and in particular that showing the harmful effects of persistent organochlorine compounds on the populations and reproductive biology 
of certain predatory birds. Much of the book, however, consists of an examination of the fierce controversy which followed Silent Spring's publication in 1962 and has raged ever since. We are left in no doubt about the deadly serious nature of the counter-attack by the pesticide champions, and the variety of tactics they have adopted. Vested interests, including not only those with financial motives in industry and agriculture, but also others concerned for political positions and scientific reputations, joined forces in an effort to destroy the Carson camp.

One can readily identify with the writer and his cause, sharing his indignation at the amount and depth of cynical unconcern, covering up, special pleading, downright deceit and shady tricks indulged in by the other side. There are indeed certain highly disturbing aspects, such as the use to which herbicides have been put in Vietnam, and the pressures brought to bear on individuals and institutions in order to make them toe the pesticide line. The 'Mississippi fish kill' is cited as one glaring example of the reckless disregard shown by some chemical manufacturers in disposing of their dangerous creations. The advocacy of a case, however, carries certain risks, and the author will no doubt be accused of bias as was his predecessor. He ends with a review of improvements in the pesticide-wildlife situation, which, while striking a hopeful note for the future, indicates that mankind has still far to go in solving the many problems involved.

D. A. RATCLIFFE

\section{Biological Studies of the English Lakes, by T. T. Macan. Longmans, 80 s.}

For nearly 40 years scientists at the Windermere laboratories of the Freshwater Biological Association, first at Wray Castle and later at the Ferry House, have studied all aspects of the freshwater biology of the Lake District: physical and chemical factors, bacteria, micro-fungi, algae, animal life both vertebrate and invertebrate (with the notable and surprising exception of Protozoa and rotifers). It was time that the results of their researches should be brought together and summarised, and no one is better qualified to do this than Dr Macan, the Deputy Director of the laboratory.

His book, however, will be mainly of interest to his fellow limnologists, for its main chapters demand for their proper understanding a more than elementary knowledge of chemistry and physics as well as a close acquaintance with freshwater organisms. The text could have had a wider appeal if, when first mentioning names such as Asterionella and Potamopyrgus, some indication had been given of even the major groups (diatoms and molluscs respectively) to which they belonged.

For the general reader the chapter on fish will probably be the most interesting, especially the results of investigations on the factors that influence the populations of various species such as trout and perch. Equally fascinating is the recent work on the history of lakes and their surroundings, as well as on past climates, revealed by deep mud cores. In particular, research on cores has led to the discarding of old ideas on the evolution of lakes as a slow process of increasing productivity due to the weathering of the rocks in the drainage areas. It is now clear that the productivity of lakes such as Windermere is increasing at a much greater rate than through these purely natural processes, viz., through enrichment by human effluents. Happily, so far, the problems that follow the enrichment of a lake such as are only too familiar in other countries have not seriously affected the Lake District. The best safeguard the area has is the 